\title{
BAX INHIBITOR-1 Is Required for Full Susceptibility of Barley to Powdery Mildew
}

\author{
Ruth Eichmann, ${ }^{1}$ Melanie Bischof, ${ }^{1}$ Corina Weis, ${ }^{1}$ Jane Shaw, ${ }^{2}$ Christophe Lacomme ${ }^{2,3}$ \\ Patrick Schweizer, ${ }^{4}$ Dimitar Duchkov, ${ }^{4}$ Götz Hensel, ${ }^{4}$ Jochen Kumlehn, ${ }^{4}$ and Ralph Hückelhoven ${ }^{1}$ \\ ${ }^{1}$ Lehrstuhl für Phytopathologie, Technische Universität München, Emil-Ramann-Straße 2, 85350 Freising-Weihenstephan, \\ Germany; ${ }^{2}$ Plant Pathology, Scottish Crop Research Institute (SCRI), Dundee DD2 5DA, U.K.; ${ }^{3}$ Science and Advice \\ for Scottish Agriculture (SASA), Virology and Zoology section, Roddinglaw Road, Edinburgh, EH12 9FJ, U.K.; ${ }^{4}$ Institute \\ of Plant Genetics and Crop Plant Research, Corrensstraße 3, 06466 Gatersleben, Germany
}

Submitted 23 March 2010. Accepted 17 May 2010.

\begin{abstract}
BAX INHIBITOR-1 (BI-1) is one of the few proteins known to have cross-kingdom conserved functions in negative control of programmed cell death. Additionally, barley BI-1 (HvBI-1) suppresses defense responses and basal resistance to the powdery mildew fungus Blumeria graminis f. sp. hordei and enhances resistance to cell death-provoking fungi when overexpressed in barley. Downregulation of $\mathrm{HvBI}-\mathrm{I}$ by transient-induced gene silencing or virus-induced gene silencing limited susceptibility to $B$. graminis f. sp. hordei, suggesting that HvBI-1 is a susceptibility factor toward powdery mildew. Transient silencing of BI-1 did not limit supersusceptibility induced by overexpression of $M L O$. Transgenic barley plants harboring an $\mathrm{HvBI-1}$ RNA interference (RNAi) construct displayed lower levels of $\mathrm{HvBI}-1$ transcripts and were less susceptible to powdery mildew than wild-type plants. At the cellular level, HvBI-1 RNAi plants had enhanced resistance to penetration by $B$. graminis f. sp. hordei. These data support a function of BI1 in modulating cell-wall-associated defense and in establishing full compatibility of $B$. graminis f. sp. hordei with barley.
\end{abstract}

On the basis of preformed and induced defense mechanisms, plants are nonhosts to the majority of potentially pathogenic microbes (Thordal-Christensen 2003). Induced defense mechanisms are mounted in response to the perception of general elicitors, also known as pathogen-associated molecular patterns (PAMPs), by pattern recognition receptors (Altenbach and Robatzek 2007; Zipfel 2008). Nonhost resistance is characterized as being effective against a broad spectrum of potential pathogens and durable over time (Schweizer 2007; Niks and Marcel 2009). Plant colonization by a pathogen is the result of a sophisticated specialization process, in which a particular microorganism gained the ability to overcome preformed defense mechanisms and to deal with PAMP-triggered immunity (PTI), most likely through the delivery of pathogen-derived effector proteins into the host cell (Chisholm et al. 2006; Jones and Dangl 2006; Bent and Mackey 2007; Boller and Felix 2009).

Ascomycete powdery mildew fungi are obligate biotrophic pathogens that can colonize all aboveground parts of a huge

Corresponding author: R. Eichmann; E-mail: r.eichmann@lrz.tum.de; Fax: +49-8161-714538;

* The $e$-Xtra logo stands for "electronic extra" and indicates that Figure 5 appears in color online. variety of land plants. In small-grain cereals, host speciesspecificity of powdery mildew fungi is high, so that a particular powdery mildew forma specialis can colonize only one specific cereal species. The barley powdery mildew fungus Blumeria graminis f. sp. hordei, for example, can infect barley (Hordeum vulgare L.) but does not grow on wheat or other cereal species (Schweizer 2007; Niks and Marcel 2009). This host species specificity might either be due to a lack of matching effector molecules on the side of the pathogen, or the lack of corresponding effector target proteins on the side of the host.

Basic compatibility can be achieved by the suppression or circumvention of resistance factor activity or the reprogramming of the host cell through targeting of host susceptibility factors. By definition, a susceptibility factor is a plant protein that is required for host susceptibility to a certain pathogen (Eckardt 2002). Consequently, loss of protein function should lead to enhanced resistance of the host plant to this particular pathogen, whereas its overexpression can support plant colonization by the intruder (Hückelhoven 2005). One of the most prominent susceptibility factors in a plant-pathogen interaction that fulfills these requirements is the barley seven transmembrane domain protein MILDEW LOCUS O (MLO). In barley, loss of MLO function in mlo-plants results in complete, race-nonspecific resistance to otherwise virulent barley powdery mildew fungi. This broad-spectrum resistance is associated with papilla formation and hydrogen-peroxide accumulation and stops the fungus at a prepenetration stage (Stolzenburg et al. 1984; Hückelhoven et al. 1999). However, it is not known whether MLO is a direct target of effector activity and which MLO-dependent signaling processes eventually result in accessibility of the host cell to powdery mildew haustoria (O'Connell and Panstruga 2006). Nevertheless, the requirement for MLO for susceptibility to powdery mildew fungi was found in dicotyledonous plant species as well (Consonni et al. 2006; Bai et al. 2008; Feechan et al. 2008), indicating a conserved pathway for defense suppression.

Among other barley proteins, which are required for full powdery mildew susceptibility, there are a WRKY transcription factor, the RHO-like GTPase RACB, the small peptide BLUFENSIN, and calmodulin (Kim et al. 2002; Schultheiss et al. 2002; Eckey et al. 2004; Meng et al. 2009).

BAX INHIBITOR-1 (BI-1) proteins are endoplasmic reticulum (ER)-resident negative regulators of stress-related cell death in plants and animals (Hückelhoven 2004; Watanabe and Lam 2009). Stable overexpression of this cell-death inhibitor in barley reduces susceptibility to the necrotrophic fungus Fusa- 
rium graminearum (Babaeizad et al. 2009). However, BI-1 not only negatively regulates cell death reactions but was also found to act as negative regulator of resistance to biotrophic powdery mildew fungi in barley. Transient or stable overexpression of $B I-1$ strongly supported penetration of B. graminis f. sp. hordei into barley epidermal cells (Hückelhoven et al. 2003; Eichmann et al. 2004, 2006b; Babaeizad et al. 2009). Moreover, transient overexpression of $B I-1$ even allowed $B$. graminis f. sp. hordei to break mlo-mediated penetration resitance and the nonadapted wheat powdery mildew fungus to penetrate epidermal cells of barley (Hückelhoven et al. 2003; Eichmann et al. 2004, 2006b). BI-1 overexpression also suppressed a local defense-related hydrogen peroxide burst at sites of interaction with B. graminis f. sp. hordei (Eichmann et al. 2006b). However, transient knockdown experiments using an antisense construct or in vitro-synthesized double-stranded RNA were inconclusive (Hückelhoven et al. 2003). Here, we show that $B I-1$ is differentially expressed in powdery mildewtargeted barley leaf epidermal tissue. We used improved RNA interference (RNAi)-based methods to show the possible role of BI-1 as a susceptibility factor. Transient and stable gene silencing experiments indicate that $B I-1$ expression is required for full susceptibility of barley to B. graminis f. sp. hordei, and
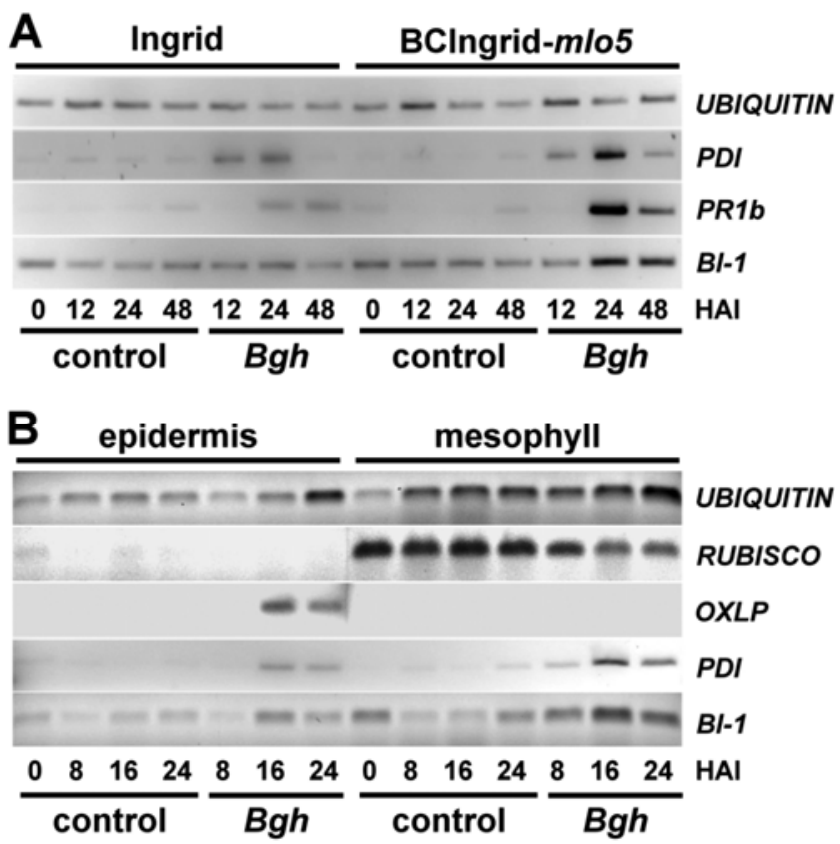

Fig. 1. Cultivar- and tissue-specific gene expression of BAX INHIBITOR-1 $(B I-1)$ in the interaction of barley with Blumeria graminis f. sp. hordei $(B g h)$. A, Total RNA was isolated from B. graminis f. sp. hordei-inoculated barley cv. Ingrid and BCIngrid-mlo5 leaves that were harvested at 12,24 , and $48 \mathrm{~h}$ after inoculation (HAI), and mock-inoculated control leaves that were harvested $0,12,24$, and $48 \mathrm{HAI}$. Inverted gel photographs after ethidium bromide staining of two-step reverse-transcription polymerase chain reaction (RT-PCR) products are shown. Amplification of $U B I Q-$ UITIN served as control for constitutive gene expression, and PROTEIN DISULFIDE ISOMERASE (PDI) and PATHOGENESIS-RELATED PROTEIN $1 b(P R 1 b)$ as control for pathogenesis-related gene expression. B, Total RNA was isolated from B. graminis f. sp. hordei- or mock-inoculated barley cv. Ingrid leaves that were harvested at $0,12,24$, and $48 \mathrm{HAI}$. At each time point, abaxial epidermal peels and remaining leaf tissue (mesophyll and adaxial epidermis) were collected separately. Inverted gel photographs after ethidium bromide staining of two-step RT-PCR products are shown. Amplification of UBIQUITIN served as control for tissue-unspecific constitutive gene expression, RIBULOSE BISPHOSPHATE CAR$B O X Y L A S E$ (RUBISCO) as control for mesophyll cell-specific gene expression, and OXALATE OXIDASE LIKE PROTEIN (OXLP) and PDI as control for epidermis-specific and general pathogenesis-related gene expression, respectively. that its transcriptional downregulation can influence penetration resistance to $B$. graminis f. sp. hordei.

\section{RESULTS}

$H v B I-1$ expression increases

in epidermal tissue after B. graminis f. sp. hordei infection.

To evaluate powdery mildew-dependent gene expression reprogramming in barley plants, we inoculated first leaves of the susceptible barley cv. Ingrid and of its race-nonspecific powdery mildew-resistant back-cross line BCIngrid-mlo5, which does not express a functional MLO protein. We measured B. graminis f. sp. hordei-responsive gene expression by semiquantitative reverse-transcription polymerase chain reaction (RT-PCR). Expression of PROTEIN DISULFIDE ISOMERASE $(P D I)$ and PATHOGENESIS-RELATED PROTEIN $1 b(P R I b)$ were examined as positive controls for defense-associated gene expression (Bryngelsson et al. 1994; Eichmann et al. 2006a). In susceptible barley cv. Ingrid, a slight accumulation of PDI transcript was observed at 12 and $24 \mathrm{~h}$ after inoculation (HAI) with B. graminis f. sp. hordei, which preceded that of $P R I b$ (Fig. 1A). Defense-associated expression of PDI and $P R 1 b$ was somewhat stronger in the resistant BCIngrid-mlo5 genotype when compared with the near-isogenic $M L O$ wild type. $B I-1$ transcript accumulated at a low level in noninoculated leaves regardless of the barley genotype. BI-1 expression slightly increased from $24 \mathrm{HAI}$ onward and was more prominent in resistant BCIngrid-mlo5 (Fig. 1A).

To examine whether $B I-1$ transcript accumulation increased in barley epidermal cells, the only tissue $B$. graminis f. sp. hordei infects, we densely inoculated the abaxial side of barley cv. Ingrid first leaves with $B$. graminis f. sp. hordei spores. At given time points after inoculation, we collected stripped abaxial epidermis and remaining leaf tissue separately. The UBIQUITIN gene was constitutively expressed regardless of tissue and treatment. Amplification of RIBULOSE BISPHOSPHATE CARBOXYLASE (RUBISCO) served as control to monitor mesophyll contamination. Hardly any RUBISCO transcript was detected in stripped epidermis, indicating proper tissue separation of the samples (Fig. 1B). In contrast, an epidermis-specific OXALATE OXIDASE-LIKE PROTEIN (OXLP, also known as GERMIN4) (Wei et al. 1998) gene showed $B$. graminis $\mathrm{f}$. sp. hordei-specific transcript accumulation only in the epidermis (Fig. 1B). PDI was B. graminis f. sp. hordei responsively expressed in the epidermis and remaining leaf tissue, with the strongest signals at 16 and 24 HAI. BI- 1 was expressed in the epidermis and its transcript accumulated in response to B. graminis f. sp. hordei, showing enhanced levels in inoculated leaf samples by 16 and 24 HAI in both epidermal and mesophyll tissue (Fig. 1B). Taken together, BI-1 is expressed in both epidermal and mesophyll tissue of barley leaves and its transcript level slightly increases in response to B. graminis f. sp. hordei infection.

Both virus- and transient-induced gene silencing of $B I-1$ in barley enhance resistance to $B$. graminis f. sp. hordei.

To test whether BI-1 is required for susceptibility to the barley powdery mildew fungus, we employed two different transient RNAi-based gene silencing methods. Virus-induced gene silencing (VIGS) has been used to examine the function of genes associated with resistance of barley to powdery mildew (Hein et al. 2005). Transient-induced gene silencing (TIGS) is based upon particle bombardment-mediated transformation of single barley epidermal cells and has been optimized for investigation of cell autonomous gene function during cereal-powdery mildew interactions (Douchkov et al. 2005). BLAST-based searches against available barley sequences indicated that $\mathrm{HvBI}-1$ (Gen- 
Bank accession number AJ290421) was the only target sequence of all RNAi constructs used in this study. For VIGS, we inoculated first leaves of barley cv. Clansman plants with a Barley stripe mosaic virus (BSMV) vector construct containing a BI-I antisense cDNA fragment (BSMV.BI-1as) (Fig. 2A) in order to silence the $B I-1$ gene in systemic leaves. Control plants were either mock inoculated or inoculated with a BSMV green fluorescent protein (GFP) construct as a control (Hein et al. 2005). By 11 days after infection, asymptomatic systemic leaves were detached and inoculated with spores of B. graminis f. sp. hordei isolate $\mathrm{CH} 4.8$. Three days after inoculation, leaves were fixed and fungal structures were stained. To evaluate the level of resistance on BI-1-silenced and control leaves, we microscopically evaluated the percentage of spores that developed elongated secondary hyphae (ESH) after penetration of the host epidermis. Interestingly, approximately twice as many fungal spores produced ESH on systemic leaves of BSMV.GFP challenge-inoculated plants than on mock-inoculated plants (Fig. 2A). In contrast, fungal development was reduced on $B I-1$ silenced leaves. Only $25 \%$ of the germinated fungi produced ESH on BI-1- silenced plants compared with control plants (Fig. 2A), indicating enhanced resistance to fungal infection. Suppression of $B I-1$ mRNA accumulation after BSMV.BI-1as challenge was confirmed by semiquantitative RT-PCR (Fig. 2B). BI-1 expression was examined in the same systemic leaves of mock-, BSMV.GFP-, and BSMV.BI-1as-inoculated plants that were used for the B. graminis f. sp. hordei resistance test. BI- 1 expression was normalized against $\alpha-2$ TUBULIN expression, which served as internal control, and then compared. BI-1 transcript accumulation appeared to be slightly higher $(90 \pm 12 \%$ standard error [SE] of the $\alpha$-2 TUBULIN signal) in BSMV.GFP-challenged plants when compared with mock-inoculated plants (67 $\pm 9 \%$ SE) but was significantly reduced in systemic leaves after infection with BSMV.BI-1as (33 $\pm 4 \%$ SE) (Fig. 2B).

Penetration success into the first attacked epidermal cell determines the outcome of the barley- $B$. graminis f. sp. hordei interaction. This allows examination of the impact of gene overor underexpression on susceptibility after ballistic transformation of barley leaf segments (Schweizer et al. 1999, 2000; Douchkov et al. 2005). Barley cv. Golden Promise leaf segments
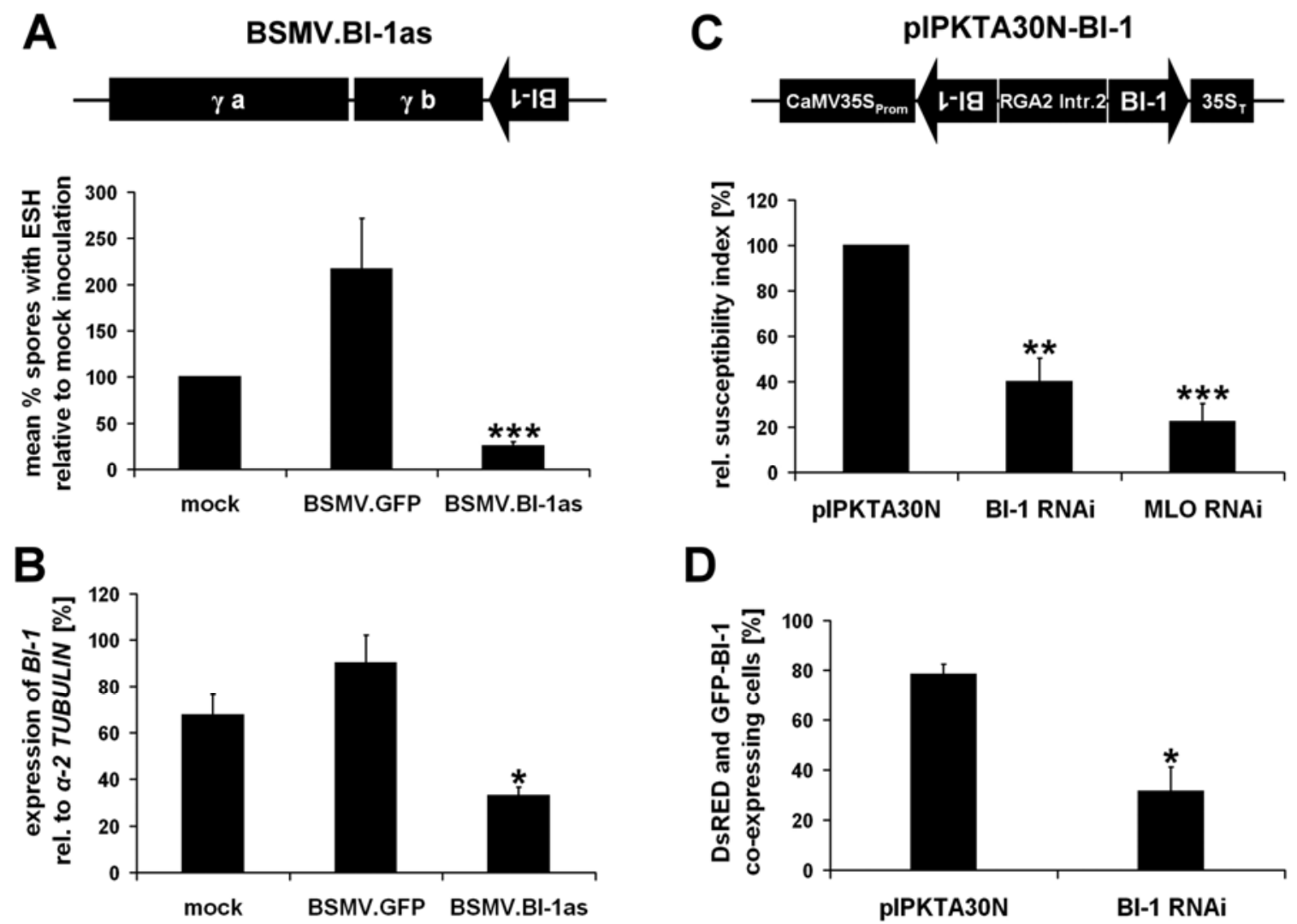

Fig. 2. Virus-induced gene silencing (VIGS) or transient-induced gene silencing (TIGS) of BAX INHIBITOR-1 (BI-1) enhance resistance in the barleyBlumeria graminis f. sp. hordei interaction. A, Schematic drawing of the Barley stripe mosaic virus (BSMV) BI-1as VIGS construct. A cDNA fragment of $B I-1$ was cloned in antisense orientation behind the $\gamma b$ gene of the $\gamma$ subgenomic RNA. Barley cv. Clansman primary leaves were inoculated with BSMV.BI-1as or with BSMV green fluorescent protein (GFP), included as a control for BSMV infection, in addition to BSMV-noninfected (mock) plants. By 11 days after infection, asymptomatic systemic leaves were detached and inoculated with spores of B. graminis f. sp. hordei isolate $\mathrm{CH} 4.8$. Three days after B. graminis $\mathrm{f}$. sp. hordei infection, the percentage of spores that developed elongated secondary hyphae (ESH) after penetration of the host epidermis was assessed. Data are from up to six independent plants corresponding to a total of 16 leaves. B, BI-1 expression as measured by semiquantitative reverse-transcription polymerase chain reaction in the same systemic leaves of mock-, BSMV.GFP-, or BSMV.BI-1as-inoculated plants. Columns represent signal intensities of PCR products on gel photographs as measured with the ImageJ software relative to signal intensities of constitutively expressed $\alpha-2$ TUBULIN. C, Schematic drawing of the RNA interference (RNAi) cassette of pIPKTA30N-BI-1 RNAi vector, which was used for TIGS of BI-1. Inverted repeats of a BI-1 cDNA fragment are separated by intron 2 of the wheat RGA2 gene. Expression of the construct is driven and terminated by the Cauliflower mosaic virus $35 \mathrm{~S}$ promoter $\left(\right.$ CaMV $\left.35 \mathrm{~S}_{\text {Prom }}\right)$ and terminator $\left(35 \mathrm{~S}_{\mathrm{T}}\right)$, respectively. Primary leaves of barley cv. Golden Promise were co-bombarded with pUbi- $\beta$-GLUCURONIDASE (GUS) and either pIPKTA30N-BI-1 (BI-1 RNAi), pIPKTA36 (MILDEW LOCUS O [MLO] RNAi), or empty vector pIPKTA30N (control). Three days later, leaves were inoculated with B. graminis f. sp. hordei spores. The susceptibility index was calculated as the fraction of GUS cells containing at least one haustorium. Columns represent values relative to the empty-vector control. D, Elimination of GFP-BI-1 fluorescence after TIGS. Barley cv. Ingrid primary leaves were co-bombarded with pGY-1-DsRED, pGY-1-GFP-BI-1, and TIGS vector pIPKTA30N-BI-1 or empty pIPKTA30N. Two days after transformation, red fluorescing DsRED-expressing cells were examined for presence or absence of green GFP-BI-1 fluorescence. A through $\mathbf{D}$, Bars represent standard errors; *,*, and *** indicate significance at $P<0.05,0.005$, and 0.0005 , respectively, according to Student's $t$ test when compared with controls. 
were cobombarded with a $\beta$-GLUCURONIDASE (GUS) expression construct and either empty vector pIPKTA30N or $B I-1$ RNAi vector pIPKTA30N-BI-1 (Fig. 2C). Similarly, GUS was coexpressed with an $M L O$ RNAi construct (pIPKTA36) (Douchkov et al. 2005). Three days after transformation, leaf segments were densely inoculated with spores of $B$. graminis $\mathrm{f}$. sp. hordei isolate $\mathrm{CH} 4.8$ and two days later inspected for GUSexpressing cells using a bright-field microscope. The susceptibility index was assessed as percentage of transformed, GUS-expressing cells that contained at least one haustorium (Douchkov et al. 2005). Average susceptibility indices relative to the control, which was set as $100 \%$, are shown in Figure 2C. Fungal penetration into $B I-1$-silenced cells was clearly restricted and occurred in only $40 \pm 10 \%$ SE of the transformed cells relative to control cells. Expectedly, reduction in penetration efficiency was even stronger in barley epidermal cells that expressed an $M L O$ RNAi construct. Here, the relative susceptibility index was $22 \pm$ $8 \%$ SE. We repeated the $B I-1$ knockdown experiments but used GFP instead of GUS and B. graminis f. sp. hordei race A6 on barley cv. Ingrid. In these experiments, a shorter period $(24 \mathrm{~h})$ of gene silencing before inoculation led to a somewhat weaker but still significant reduction of fungal penetration success by approximately $30 \%$ (data not shown).

To further prove the efficiency of the BI-1 RNAi construct, we examined its capacity to silence the expression of a GFP$B I-1$ translational fusion construct. To this end, we cobombarded barley cv. Ingrid leaf segments with pGFP-BI-1 and either empty vector pIPKTA30N or pIPKTA30N-BI-1. Additionally, we delivered DsRED as transformation marker (Dietrich and Maiss 2002). Two days after transformation, red fluorescing DsRED cells were examined for the presence or absence of green fluorescence of the GFP-BI-1 fusion protein. Although $78 \pm 4 \%$ SE of control cells displayed GFP-BI- 1 expression, green fluorescence was strongly suppressed after delivery of pIPKTA30N-BI-1 and could be detected in $31 \pm 10 \%$ SE of the DsRED-positive cells only (Fig. 2D).

Together, VIGS and TIGS provided evidence for the contribution of $B I-1$ to barley susceptibility to infection by $B$. graminis f. sp. hordei.

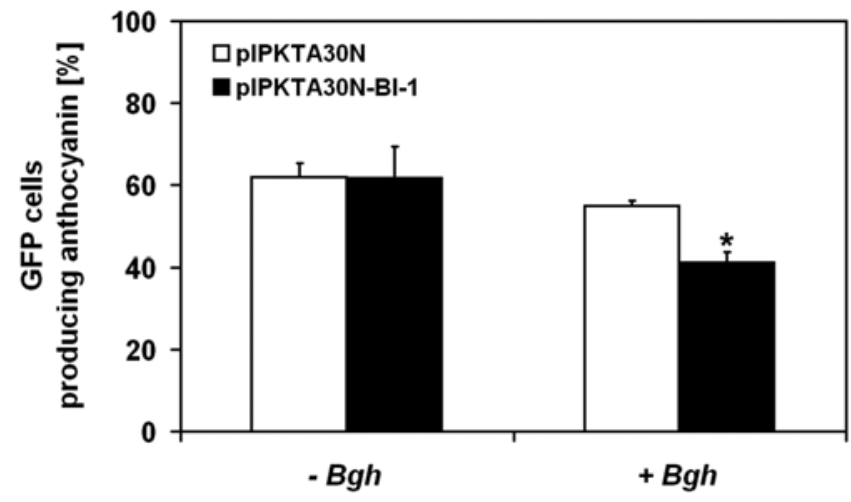

Fig. 3. Anthocyanin accumulation, indicative of cell viability, decreases in BAX INHIBITOR-1 (BI-1)-silenced cells after Blumeria graminis f. sp. hordei inoculation. Quantitative analysis of the number of green fluorescent protein (GFP)- and anthocyanin-accumulating cells in the presence of empty pIPKTA30N or pIPKTA30N-BI-1 without $(-B g h)$ and with $(+B g h)$ powdery mildew inoculation. Barley cv. Golden Promise plants were transiently transformed with either empty vector or BI-1 transient-induced gene-silencing construct pIPKTA30N-BI-1. Cells were co-bombarded with pGY-1-GFP as transformation marker and the $B$-Peru/C1-expression plasmid pBC17 for anthocyanin production. Note that anthocyanin accumulation is never seen in dead cells. Columns represent mean values of three independent experiments. Bars represent standard errors; * indicates significance at $P<0.05$ according to Student's $t$ test when compared with the respective empty vector control.
HvBI-1 has been shown to inhibit pathogen-induced cell death reactions in barley (Eichmann et al. 2006b; Babaeizad et al. 2009). Therefore, we assessed whether the enhanced resistance to B. graminis f. sp. hordei in BI-l-silenced cells was associated with cell death. The accumulation of anthocyanin pigments after transient expression of the maize genes B-Peru and $C l$ in barley only occurs in intact vacuoles of viable cells. Therefore, we used cotransformation of RNAi vector pIPKTA$30 \mathrm{~N}-\mathrm{BI}-1$ together with the $\mathrm{B}$-Peru/Cl-expression plasmid pBC17 (Schweizer et al. 2000) to evaluate the potential effect of $B I-1$ silencing on cell death. Cotransformation of $\mathrm{pBC} 17$ with empty vector pIPKTA30N served as control. GFP was used as an additional transformation marker. The experiment was performed with and without dense B. graminis f. sp. hordei inoculation (more than $50 \%$ of all epidermal cells were attacked by the fungus). If $B I-1$ silencing would affect viability of the cells, the percentage of GFP- and anthocyanin-coaccumulating cells should be lower when compared with control cells. In the absence of powdery mildew conidia, approximately $60 \%$ of the GFP-expressing cells also displayed anthocyanin accumulation, regardless of whether $B I-1$ was silenced or cells were transformed with empty vector (Fig. 3). However, upon inoculation with spores of $B$. graminis f. sp. hordei, the proportion of anthocyanin accumulating cells was lower after $B I-1$ silencing $(41 \pm 2 \% \mathrm{SE})$ when compared with control cells (55 $\pm 1 \%$ SE) (Fig. 3), indicating that B. graminis f. sp. hordei can induce a certain degree of barley epidermal cell death when $B I-1$ expression was reduced. However, no such effect was observed without pathogen inoculation.

Knockdown of BI-1 expression by TIGS does not suppress supersusceptibility induced by $M L O$ overexpression.

Because overexpression of HvBI-1 compromised mlo5-mediated resistance (Hückelhoven et al. 2003), we asked whether induction of susceptibility by $M L O$ overexpression (Shirasu et al. 1999) can be reduced by simultaneous silencing of $B I-1$. Therefore, we ballistically transferred an $M L O$ overexpression construct together with either the TIGS vector pIPKTA30NBI- 1 or the empty vector pIPKTA30N into epidermal cells of

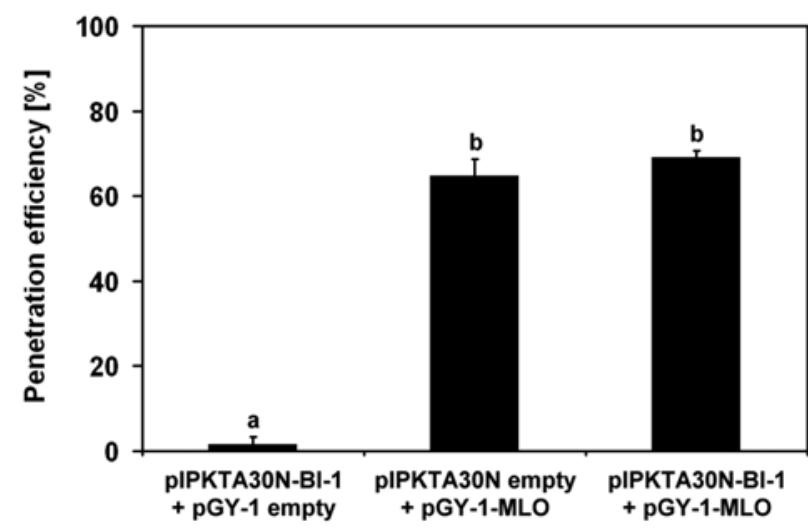

Fig. 4. Knockdown of $B A X I N H I B I T O R-1$ (BI-1) expression does not limit defense suppression by MILDEW LOCUS $O(M L O)$ overexpression. Leaves of the Blumeria graminis f. sp. hordei-resistant barley backcross line Pallas-mlo5 were transiently transformed by particle bombardment. Expression construct pGY-1-MLO was co-expressed with either BI-1 RNA interference construct pIPKTA30N-BI-1 or empty vector pIPKTA30N. Control cells were co-bombarded with pIPTKTA30N-BI-1 and empty vector pGY1. Two days after transformation, leaves were densely inoculated with $B$. graminis f. sp. hordei conidia. Microscopic determination of B. graminis $\mathrm{f}$. sp. hordei penetration efficiency into transformed cells was assessed 2 days later. Columns represent mean values of three independent experiments. Bars represent standard errors. Averages highlighted with the same letter are not statistically different at $P<0.05$ according to Student's $t$ test. 
the $B$. graminis f. sp. hordei-resistant barley backcross line BCPallas-mlo5. Control cells were cobombarded with empty pGY-1 vector and pIPKTA30N-BI-1. GFP served as transformation marker. Two days after bombardment, leaf segments were densely inoculated with $B$. graminis f. sp. hordei conidia. After another 2 days, powdery mildew penetration efficiency (i.e., the percentage of attacked transformed cells that contained at least one haustorium) was assessed. As expected, penetration efficiency was very low $(2 \pm 2 \% \mathrm{SE})$ in control mlo5 cells without $M L O$ overexpression (Fig. 4). Overexpression of $M L O$ strongly increased fungal penetration efficiency to $65 \pm 4 \%$ SE (Fig. 4). $M L O$-mediated increase in susceptibility was not limited by simultaneous knockdown of $B I-1$ expression. Penetration efficiency here was $69 \pm 5 \%$ SE (Fig. 4).

\section{Stable knockdown of $B I-1$ expression reduces}

$B$. graminis f. sp. hordei colonization on barley plants.

Stable transgenic barley plants, expressing a BI-1 RNAi cassette under the control of the strong constitutive maize $U B I Q$ UITIN1 promoter (Fig. 5A), were produced. Altogether, transgenic plants of 18 different lines of the T1 generation were tested in inoculation experiments for enhanced resistance to colonization by $B$. graminis f. sp. hordei. We identified two lines, BG37/2E10 and BG37/2E11, that showed a consistently decreased colonization by $B$. graminis f. sp. hordei in repeated experiments. The first leaf was used to prove the presence of the transgene by either PCR or a hygromycin-resistance test. Leaf segments of the second leaf were then placed on water agar plates and inoculated with $B$. graminis f. sp. hordei conidia. After 5 to 7 days, powdery mildew colonies became visible. Representative examples of reduced powdery mildew colonization in individual plants of the segregating T1 population, which coincided with suppressed BI-l expression, are shown in Figure 5B and C. Here, total RNA was extracted from third leaves of individual plants and semiquantitative RTPCR was performed to examine $B I-1$ expression. Constitutive expression of the UBIQUITIN gene was used to demonstrate equal amounts of RNA template. $B I-1$ expression was downregulated in plants of $B I-1$ RNAi lines BG37/2E10 (E10) and
BG37/2E11 (E11) but not of line BG37/2E05 (E05) (Fig. 5B). $B I-1$-silenced plants showed a clearly reduced number of powdery mildew pustules when compared with either wild-type (WT GP) or nonsilenced plants (Fig. 5C). In all experiments, transgenic plants of lines BG37/2E10 and BG37/2E11 showed a reduction in pustule development after inoculation whereas line BG37/2E05 behaved like the wild type. One of the repeated experiments is summarized in Figure 5D. Taken together, data from stable transgenic BI-1 RNAi plants further support results form $B I-1$ TIGS and VIGS experiments, hereby confirming that silencing of $B I-1$ restricts colonization by $B$. graminis f. sp. hordei.

\section{Enhanced resistance in stable, transgenic $B I-1$ RNAi plants} is associated with papilla formation

but not constitutive upregulation of defense-related genes.

Transmission of BI- 1 silencing and corresponding resistance into the T2 and T3 transgenic generation was inconsistent, although the T-DNA was inherited as expected (data not shown). We performed quantitative real-time PCR to assess residual BI- 1 expression in pooled RNA extracted from T1 plants of line BG37/2E10 (E10), which consistently showed reduced colonization by B. graminis f. sp. hordei. Expression of BI-1 in BG37/2E10 was strongly decreased and corresponded to $26 \pm$ $0.4 \%$ standard deviation of that in Golden Promise wild type (GP WT) plants (Fig. 6A). In order to investigate the mechanism underlying enhanced resistance in T1 BI-l RNAi plants, second leaves of intact plants of line BG37/2E10 and GP WT, as well as individuals that lost the T-DNA due to segregation (azygous controls), were inoculated with B. graminis f. sp. horde $i$ spores. At $30 \mathrm{HAI}$, inoculated leaves were detached and transferred to 3,3-diaminobenzidine (DAB) solution for the detection of hydrogen peroxide $\left(\mathrm{H}_{2} \mathrm{O}_{2}\right)$. Leaves were inspected microscopically for the frequency of successful penetration by the fungus into barley epidermal cells, as indicated by haustorium formation and the development of elongated secondary hyphae, the frequency of papilla formation (nonpenetrated living cells), and the occurrence of the hypersensitive response (HR) as indicated by whole-cell DAB staining (Fig. 6C through
A

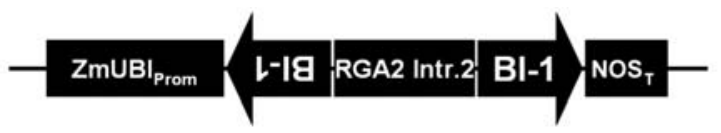

B

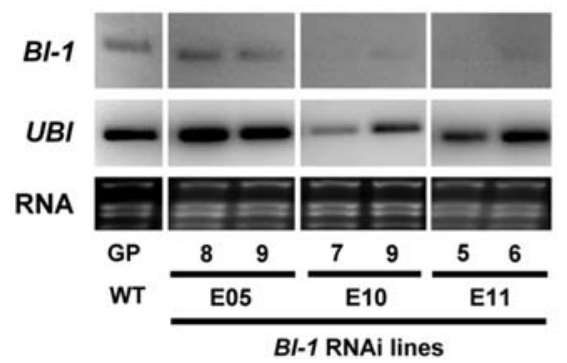

C

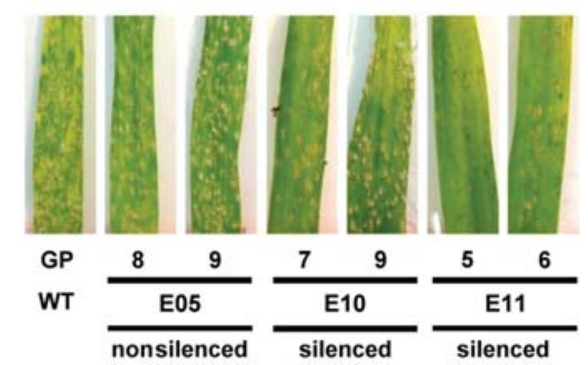

D

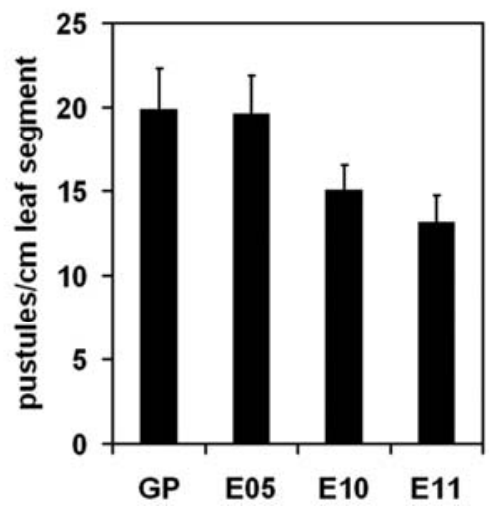

Fig. 5. BAX INHIBITOR-1 (BI-1) silencing in stable transgenic barley plants reduces colonization by Blumeria graminis f. sp. hordei. A, Schematic drawing of the RNA interference (RNAi) cassette of the binary pLH6000-BI-1 RNAi vector that was used for stable transformation of barley. Inverted repeats of a $B I-1$ cDNA fragment are separated by intron 2 of the wheat $R G A 2$ gene. Expression of the RNAi cassette is driven by the maize UBIQUITIN promoter $\left(\mathrm{ZmUBI}_{\text {Prom }}\right)$ and terminated by the NOPALINE SYNTHASE terminator $\left(\mathrm{NOS}_{\mathrm{T}}\right)$. B and $\mathbf{C}$, Pustule development on individual BI-1-silenced and nonsilenced plants. B, Total RNA of individual plants of BI-1 RNAi line BG37/2E05 (numbers 8 and 9), BG37/2E10 (numbers 7 and 9), and BG37/2E11 (numbers 5 and 6) and one wild-type Golden Promise plant (GP WT) was extracted from third leaves and BI-1 expression was analyzed by semiquantitative reverse-transcription polymerase chain reaction (RT-PCR). RT-PCR analysis of constitutively expressed UBITQUITIN (UBI) and ethidium bromide-stained total RNA were used to show similar concentrations of template RNA. Inverted gel photographs are shown. C, Development of powdery mildew pustules on the same plants that were analyzed in B. The second leaf of each plant was inoculated with B. graminis f. sp. hordei conidia. Pustule development was allowed for 7 days and then photographed. D, Second leaves of GP WT and transgene-positive plants of BI-1 RNAi lines BG37/2E05 (E05), BG37/2E10 (E10), and BG37/2E11 (E11) were inoculated with spores of B. graminis f. sp. hordei. Seven days after inoculation, pustules on a 5-cm leaf segment were counted. Columns represent mean numbers of pustules per centimeter of leaf segment. Bars represent standard errors of the means. One representative experiment is shown. 
E). Azygous controls did not differ from wild-type plants in the frequency of interaction types. In both cases, penetration frequency was approximately $37 \%$, while $60 \%$ of the attacked cells were nonpenetrated living cells and approximately $3 \%$ underwent HR (Fig. 6B). In contrast, penetration efficiency of $B$. graminis f. sp. hordei was significantly lower in leaves of $B I-1$ RNAi plants $(17 \pm 4 \%$ SE, Student's $t$ test $P<0.05,46 \%$ of the wild-type control). The drop in penetration efficiency was accompanied by a corresponding increase in the occurrence of nonpenetrated living cells $(81 \pm 5 \% \mathrm{SE})$ showing DAB staining in papillae, whereas the frequency of HR was unchanged when compared with that in wild-type and azygous control plants $(3 \pm 1 \% \mathrm{SE})$ (Fig. 6B). Microscopic data indicate that penetration resistance of BG37/2E10 largely explains enhanced resistance to powdery mildew at the symptom level. Furthermore, semiquantitative RT-PCR analysis indicated that resistance in BI- 1 RNAi plants was not accompanied by constitutive upregulation of the defense-associated genes $P A T H O$ GENESIS-RELATED PROTEIN $1 b$ and 5 (PRIb; PR5), CALRETICULIN 3 (CRT3), and BARLEY CHEMICALLY INDUCED GENE 3 (BCI-3) (data not shown).

\section{DISCUSSION}

Little is known about plant proteins involved in susceptibility to fungal pathogens. Here, we present evidence that HvBI1 is required for full accessibility of barley epidermal cells to penetration by B. graminis f. sp. hordei and subsequent symptom formation. This establishes BI-1 as a susceptibility factor involved in fungal accommodation in intact plant cells.

The intimate interaction of plants with biotrophic, haustoriaforming fungal microorganisms presumably requires a reprogramming of the host cell in favor of the pathogen. This seems to be necessary in order to support fungal accommodation in an intact plant cell and the subsequent biotrophic life style (O'Connell and Panstruga 2006). The HvBI-1 protein was a candidate susceptibility factor for powdery mildew because its transient or stable overexpression supports both pathogen entry into host cells and pustule development on barley leaves (Hückelhoven et al. 2003; Eichmann et al. 2004; Babaeizad et al. 2009). In addition, a GFP-BI-1 fusion protein strongly accumulates at sites of fungal contact with the host cell (i.e., underneath attacking appressoria or at sites of successful penetration). BI-1 overexpression also suppressed a local oxidative burst that is normally associated with penetration resistance (Hückelhoven et al. 1999; Eichmann et al. 2006b). However, direct proof for the requirement of BI-1 for pathogenesis was lacking, due to the fact that previous RNAi-based transient $B I$ 1 knockdown experiments using either in vitro transcribed double-stranded RNA or an antisense construct did not reliably influence the interaction with $B$. graminis f. sp. hordei (Hückelhoven et al. 2003) and, thus, evidence was based on overexpression only. Here, we used improved RNAi-based methods to downregulate $B I-1$ expression in the context of $B$.
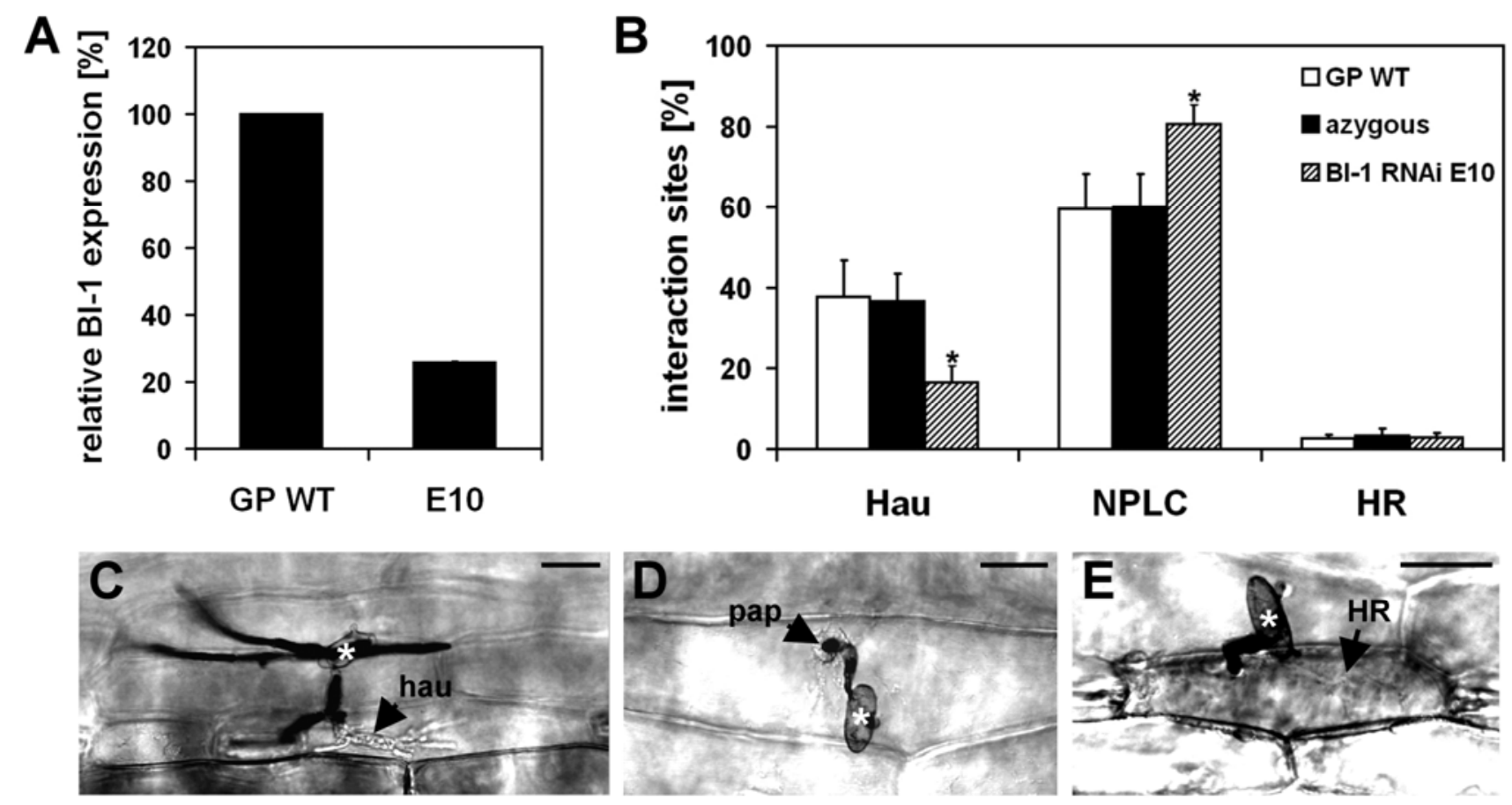

Fig. 6. Microscopic inspection of the interaction of BAX INHIBITOR-1 (BI-1)-silenced and wild-type (WT) barley plants with Blumeria graminis f. sp. hordei at $36 \mathrm{~h}$ after inoculation. A, Analysis of BI-1 expression in BI-1 RNA interference (RNAi) line BG37/2E10 (E10) by quantitative real-time polymerase chain reaction. Total RNA was extracted from the third leaf of four randomly selected plants that were positive for the presence of the transgene, then pooled. BI-1 expression level was normalized against barley UBIQUITIN CONJUGATING ENZYME and is presented relative to the expression level in WT Golden Promise (GP WT), which was set as $100 \%$. Columns represent mean values of three technical repetitions. Bar represents standard deviation. B, Second leaves of BI-1 RNAi line BG37/2E10 (BI-1 RNAi E10, eight leaves) as well as corresponding azygous controls that had lost the transgene due to segregation (three leaves) and parental line GP WT (five leaves) were inoculated with spores of the barley powdery mildew fungus and, $30 \mathrm{~h}$ later, stained with 3,3-diaminobenzidine (DAB) for $6 \mathrm{~h}$ for detection of hypersensitive response (HR) by whole-cell $\mathrm{H}_{2} \mathrm{O}_{2}$ staining. Successful fungal penetration was indicated by haustorium formation (Hau) and development of elongated secondary hyphae. Nonpenetrated cells either survived fungal attack (nonpenetrated living cells [NPLC]) or displayed HR without visible haustorium formation. Bars represent standard errors; * indicates significance at $P<0.05$ according to Student's $t$ test when compared with GP WT. C through E, Exemplary pictures of the B. graminis f. sp. hordei interaction types evaluated in B. Extracellular fungal structures appear dark due to staining with acetic ink. Asterisks mark fungal spores. Size bars $=30 \mu \mathrm{m}$. C, Successful fungal penetration into a barley epidermal cell as indicated by haustorium formation (hau). D, Nonpenetrated living cell. The fungus could not penetrate the attacked and still-intact cell, possibly due to papilla (pap) formation. E, Barley epidermal cell that responded with an HR to fungal attack. Note that the whole cell appears dark due to dark precipitates after DAB staining of $\mathrm{H}_{2} \mathrm{O}_{2}$. 
graminis f. sp. hordei infection and showed its impact on the outcome of the interaction.

\section{$H v B I-1$ expression increases}

in epidermal tissue after B. graminis f. sp. hordei infection.

The interaction of the barley powdery mildew fungus with its host plant takes place at the epidermal cell layer. A powdery mildew-induced increase in $B I-1$ expression was reported previously, using whole leaves (Hückelhoven et al. 2001; Eichmann et al. 2004). However, previous studies did not clearly show whether or not $B I-1$ transcripts are present in the epidermis (Hückelhoven et al. 2003). Here, we analyzed pathogen-dependent $B I-1$ expression in the epidermis in more detail and found that weak constitutive expression of $B I-1$ in the epidermis slightly increased at 16 and $24 \mathrm{~h}$ after B. graminis f. sp. hordei inoculation, which coincides with attempts for host cell penetration and haustorium establishment under the conditions applied (Hückelhoven et al. 1999; Eichmann and Hückelhoven 2008). BI-1 expression in epidermal leaf tissue and its $B$. graminis f. sp. hordei-induced transcript accumulation were also evident from global gene-expression studies using barleyPGRC1 10K cDNA arrays (Schweizer 2008) (P. Schweizer, unpublished data). Epidermis expression of BI-I was also the prerequisite for the analysis of gene function by TIGS upon ballistic transformation.

\section{Both VIGS and TIGS of BI-1}

in barley enhanced resistance to $B$. graminis f. sp. hordei.

VIGS and TIGS have been used in cereals to demonstrate the function of different proteins in barley resistance or susceptibility to powdery mildew fungi (Douchkov et al. 2005; Hein et al. 2005). Our transient gene-silencing experiments described here provide evidences that $B I-1$ knockdown limits susceptibility of barley epidermal cells to B. graminis f. $\mathrm{sp}$. hordei haustorium establishment. This effect was observed with two different fungal isolates and in three different barley genetic backgrounds, suggesting a perhaps general requirement of BI-1 for full susceptibility to B. graminis f. sp. hordei. In barley, several genes have been shown by TIGS to be involved in susceptibility to powdery mildew. Among them are the small RHO-like G-protein RACB, a WRKY transcription factor, BLUFENSIN1, calmodulin, and MLO (Kim et al. 2002; Schultheiss et al. 2002; Eckey et al. 2004; Meng et al. 2009). However, only in the case of MLO was this function demonstrated at the whole-plant level because mlo-null mutants are completely resistant to $B$. graminis f. sp. hordei (Jørgensen 1992; Büschges et al. 1997). It is not understood to which extent genes that contribute to susceptibility operate in the same or overlapping pathways. For calmodulin and RACB, an MLO-cooperative function has been suggested based on protein-protein interaction studies or indirect genetic evidence, respectively (Kim et al. 2002; Lorek et al. 2010). It has also been hypothesized that BI-1 could function downstream of or in parallel with MLO, because overexpression of BI-1 partially substituted for MLO function in susceptibility to B. graminis $\mathrm{f}$. sp. hordei in an mlo-null mutant background (Hückelhoven et al. 2003; Eichmann et al. 2006b). Additionally, both MLO and BI-1 share the ability to break resistance to the nonadapted wheat powdery mildew fungus $B$. graminis f. sp. tritici when transiently overexpressed (Elliott et al. 2002; Eichmann et al. 2004). Coexpression of MLO and BI-1 did not result in further increase in susceptibility to $B$. graminis f. sp. tritici when compared with individual overexpression of the genes (Eichmann et al. 2004). Our gene-silencing experiments in $M L O$ or mlo genotypes now show that knockdown of $B I-1$ expression restricts susceptibility in MLO genotypes but cannot limit supersusceptibility induced by overexpressed MLO in an mlo5- mutant background (Fig. 4). This suggests that BI-1 acts in parallel to rather than downstream of MLO.

Enhanced resistance in stable, transgenic BI-1 RNAi plants is associated with papilla formation

but not constitutive upregulation of defense-related genes.

BI-1 has the ability to suppress cell death in plants induced by diverse triggers, including biotic stress (Watanabe and Lam 2009). The knockout of cell death regulator proteins often results in a lesion mimic phenotype, including spontaneous or abiotically induced leaf cell death and stress-related gene expression (Lorrain et al. 2003). Interestingly, MLO controls salicylic acid-independent penetration resistance to powdery mildew in Arabidopsis, whereas spontaneous defense reactions and cell death in mlo mutants require salicylic acid (Consonni et al. 2006). TIGS of BI-1 did not lead to spontaneous death of cells, as assessed from the number of transformed cells that expressed a GFP marker protein and accumulated anthocyanin pigments as a result of $B$-Peru/Cl-expression on detached leaves. Additionally, transgenic BI- 1 RNAi plants had a wild-type phenotype and did not show spontaneous lesion formation or defense-associated gene expression. Hence, partial knockdown of BI- 1 did not influence the viability of nonstressed barley cells.

The induced death of attacked but nonpenetrated cells is part of the basal defense reaction of barley to B. graminis f. sp. hor$d e i$. When inoculated with $B$. graminis f. sp. hordei, TIGS of BI1 moderately but significantly lowered the number of transformed single cells that showed simultaneous GFP-fluorescence and anthocyanin accumulation on leaf segments, perhaps indicating B. graminis f. sp. hordei-induced cell death when BI-I expression is down. Consistently, stable overexpression of GFPBI-1 lowered the frequency of B. graminis f. sp. hordei-induced cell death on detached leaves (Babaeizad et al. 2009). However, intact, stable transgenic BI-1 RNAi-plants did not show more frequent $B$. graminis f. sp. hordei-induced cell death but, exclusively, penetration resistance associated with formation of DABstained papilla (Fig. 6B). We have observed before that detached leaves show a higher frequency of $B$. graminis f. sp. hordeiinduced cell death when compared with intact plants (Pathuri et al. 2008; unpublished data). Together, BI-1 seems to influence B. graminis f. sp. hordei-induced cell death on detached leaves only but influences penetration resistance on both detached leaves and intact plants. Hence, BI-1 might be involved in celldeath control and cell-wall-associated prepenetration defense, albeit in potentially distinct pathways. Together, data support that silencing of BI- 1 did not simply suppress biotrophy but limited accessibility to fungal penetration.

Similar to stable knockdown of BI-1 in barley, an Arabidopsis BI-1 (AtBI-1) null mutant did not show spontaneous cell death but did show enhanced sensitivity to a fungal toxin and to an avirulence factor of Pseudomonas syringae (Watanabe and Lam 2006; Kawai-Yamada et al. 2009). Transient ballistic overexpression of Arabidopsis BI-1 (AT5G47120) under control of the Cauliflower mosaic virus (CaMV) 35S promoter in barley leaf segments significantly enhanced susceptibility to penetration by $B$. graminis f. sp. hordei, indicating a conserved ability of monocot and dicot BI-1 proteins to support accessibility to B. graminis f. sp. hordei (C. Weis, unpublished results).

Collectively, our transient and stable gene-silencing assays demonstrate a contribution of the BI-1 protein to susceptibility of barley to the powdery mildew fungus $B$. graminis f. sp. hordei.

Little is known about the mode of BI-1 action. The protein is involved in the ER-stress response (Watanabe and Lam 2009) and was suggested to build a membrane pore that may be involved in cross-membrane transport of ions (e.g., $\mathrm{Ca}^{2+}$ ) (IharaOhori et al. 2007). A role in $\mathrm{Ca}^{2+}$ homoeostasis of the ER is sup- 
ported because BI-1 is a membrane-resident ER protein and knockout or overexpression of BI-1 modulate the amount of ERreleasable $\mathrm{Ca}^{2+}$ (Chae et al. 2004). The fact that AtBI-1 interacts with calmodulin further supports a role in $\mathrm{Ca}^{2+}$ signaling (IharaOhori et al. 2007). Very recently, it was shown that AtBI-1 could interact with Arabidopsis fatty acid hydroxylases via Cytochrome b5 in planta, and that overexpression of AtBI- 1 increases the level of very long chain fatty acids, which are typically incorporated into sphingolipids (Nagano et al. 2009). Sphingolipids are involved in cell death activation in plants and are components of lipid raft-like detergent resistant membrane microdomains, which are thought to be important for processes such as signal transduction, membrane trafficking, cytoskeletal organization, and pathogen entry (Bhat et al. 2005; Raffaele et al. 2009). How far these possible modes of action are also involved in BI-1 function in powdery mildew susceptibility in barley needs to be examined in future experiments.

\section{MATERIALS AND METHODS}

\section{Plants, pathogen, and inoculation.}

The barley $(H$. vulgare L.) cv. Ingrid and its corresponding backcross line BCIngrid-mlo5 (I22) as well as Pallas backcross line BCPallas-mlo5 (P22) were obtained from L. Munk (Royal Veterinary and Agricultural University, Copenhagen, Denmark). Plants were grown in a growth chamber at $18^{\circ} \mathrm{C}$ with $60 \%$ relative humidity and a photoperiod of $16 \mathrm{~h}\left(60 \mu \mathrm{mol} \mathrm{m} \mathrm{m}^{-2} \mathrm{~s}^{-1}\right.$ photon flux density). Barley powdery mildew fungus $B$. graminis $\mathrm{f}$. sp. hordei, race A6, was inoculated on the adaxial side of primary or secondary barley leaves, giving a density of 5 conidia $\mathrm{mm}^{-2}$ for macroscopic evaluation of pustule development, 20 conidia $\mathrm{mm}^{-2}$ for microscopic analysis, or 100 conidia $\mathrm{mm}^{-2}$ for gene-expression studies. For tissue-specific gene-expression studies, the abaxial side of primary leaves was inoculated and later peeled off. For gene-expression analysis as well as microscopic and macroscopic inspection, intact barley plants were inoculated.

\section{RNA extraction and expression analysis.}

Total RNA was extracted from frozen plant material using TRIzol reagent (Invitrogen, Karlsruhe, Germany) according to the manufacturer's instructions. For semiquantitative two-step RT-PCR, 2 to $5 \mu \mathrm{g}$ of total RNA from each sample was reverse transcribed into cDNA using the QuantiTect reverse transcription kit (Qiagen $\mathrm{GmbH}$, Hilden, Germany). Semiquantitative two-step RT-PCR reactions were performed with cycling conditions that were selected to avoid overcycling (Table 1).
VIGS.

A 450-bp cDNA fragment of BI- 1 (GenBank accession number AJ290421) was amplified by PCR using specific primers 5'-CAGCGGCCGCCACGACTCCCTCAAGAACT-3' and 5'CATATTAATTAACCAGAGCAGGATCGACA-3' and then introduced in anti-sense orientation into a $\gamma$-RNA-based BSMV vector (Holzberg et al. 2002; Lacomme et al. 2003; Hein et al. 2005) to produce BSMV.BI-1as (Fig. 2A). BSMV.GFP (Haupt et al. 2001; Hein et al. 2005) was used as control of BSMV infection. In vitro transcription from cDNA clones and preparation of BSMV infectious RNA as well as virus inoculation of barley cv. Clansman plants was performed as described by Holzberg and associates (2002) and Hein and associates (2005). BSMV noninfected plants (mock) served as an additional control.

For B. graminis f. sp. hordei microcolony development assessment after VIGS, 5-cm segments of third, fourth, or fifth leaves of BSMV- and mock-inoculated barley plants (cv. Clansman) were detached and inoculated with spores of a virulent $B$. graminis $\mathrm{f}$. sp. hordei isolate $\mathrm{CH} 4.8$, giving a density of 15 to 20 conidia $\mathrm{cm}^{-2}$ as previously described (Hein et al. 2005). Remaining segments of the same leaves were sampled in order to measure the endogenous BI-1 mRNA levels. RNA was extracted from each individual sample using the RNeasy plant mini-kit (Qiagen, Crawley, U.K.). Semiquantitative RTPCR was performed to monitor BI-1 expression levels as previously described (Lacomme et al. 2003; Hein et al. 2005). Constitutively expressed $\alpha-2$ TUBULIN (GenBank accession number Y08490) served as internal control and was amplified using specific primers 5'-CAGGCTTGTTTCTCAGGTCA-3' and 5'-ATTCAGAGCACCGTCAAACC-3', giving a fragment of 64 bp. Primers 5'-ATGGACGCCTTCTACTCGACCTC-3' and 5'-CAAAGATGGACGTGACAAACTGC-3' were used to amplify a $H v B I-1$-specific fragment of $502 \mathrm{bp}$. After gel-electrophoretic separation, ethidium bromide-stained gels were photographed and pixel intensities were measured using the software ImageJ, which is available online from the National Institutes of Health. Mean intensities of $B I-1$ signals were normalized against mean intensities of $\alpha-2$ TUBULIN signals and displayed as percentage of $B I-1$ expression relative to $\alpha-2 T U$ BULIN expression.

\section{TIGS.}

A 402-bp BI-1 cDNA fragment was amplified by PCR using gene-specific primer 5'-TAGTTCCGACACAAGCGAGC-3' and universal primer MVR-26 5'-CTCACTAAAGGGAACAA AAGCTGGAG-3' and inserted in antisense orientation into

Table 1. Primers and polymerase chain reaction (PCR) conditions for gene expression analyses by semiquantitative reverse-transcription PCR

\begin{tabular}{|c|c|c|c|c|}
\hline Identity (accession no.) & $5^{\prime}$ and $3^{\prime}$ primer sequences & Annealing temperature $\left({ }^{\circ} \mathrm{C}\right)$ & Cycle number & Product size (bp) \\
\hline \multirow[t]{2}{*}{ UBIQUITIN (M60175) } & ACCCTCGCCGACTACAACAT & $\ldots$ & $\ldots$ & \\
\hline & CAGTAGTGGCGGTCGAAGTG & 60 & 26 & 263 \\
\hline \multirow[t]{2}{*}{ RUBISCO (U43493) } & TCCTTTCCAGGGGCTCA & $\ldots$ & $\ldots$ & $\ldots$ \\
\hline & GAGGCAAGGCACCCACT & 58 & 17 & 223 \\
\hline \multirow[t]{2}{*}{ PR1b (Z26333) } & AAGCTGCAAGCGTTCGCC & $\ldots$ & $\ldots$ & $\ldots$ \\
\hline & AGGTGTTGGAGCCGTAGTC & 58 & 25 & 184 \\
\hline \multirow[t]{2}{*}{ PDI (L33252) } & GAGCCAAGGGGCTTTCCAGT & $\ldots$ & $\ldots$ & $\ldots$ \\
\hline & TGCTCAGAGCTCATCCTTCA & 55 & 25 & 604 \\
\hline \multirow[t]{2}{*}{ BI-1 (AJ290421) } & GTCCCACCTCAAGCTCGTTT & $\ldots$ & $\ldots$ & $\ldots$ \\
\hline & ACCCTGTCACGAGGATGCTT & 60 & 27 & 269 \\
\hline \multirow[t]{2}{*}{ OXLP (X93171) } & GGCCGACATGCATTCACCAG & $\ldots$ & $\ldots$ & $\ldots$ \\
\hline & CATCTGATATTGCTGGGTCTG & 57 & 25 & 506 \\
\hline \multirow[t]{2}{*}{ BCI3 (AJ628169) } & GTCATCGACCAGGCCATC & $\ldots$ & $\ldots$ & $\ldots$ \\
\hline & GTACGCGTCGAAGCTCGT & 58 & 24 & 165 \\
\hline \multirow[t]{2}{*}{ CRT3 (AK248906) } & TGCGATGACCCGGAAT & $\ldots$ & $\ldots$ & $\ldots$ \\
\hline & TCCGTCGCTCTCCTTCC & 55 & 35 & 154 \\
\hline \multirow[t]{2}{*}{ PR5 (AJ276225) } & CGGCGGTGCTCTTCC & $\ldots$ & $\ldots$ & $\ldots$ \\
\hline & GGCGGGCACGTTGAT & 60 & 25 & 164 \\
\hline
\end{tabular}


the pIPKTA38 Gateway compatible entry vector (Douchkov et al. 2005). The BI-1 cDNA fragment was then introduced as inverted repeats into the pIPKTA30N destination vector (Douchkov et al. 2005) by a standard Gateway LR reaction. The resulting RNAi construct pIPKTA30N-BI-1 thus contained inverted repeats of BI- 1 separated by the second intron of the wheat RGA2 gene under the control of the strong constitutive CaMV 35S promoter (Fig. 2C).

Ballistic transformation of epidermal cells of barley cv. Golden Promise leaf segments was performed using a PDS1000/He plant transformation gun with hepta-adapter (BioRad Laboratories $\mathrm{GmbH}$, Munich), as described previously (Douchkov et al. 2005). For each shot, 1- $\mu \mathrm{m}$ gold particles were coated with $7 \mu \mathrm{g}$ of $p U b i G U S$ (uida, GUS gene from Escherichia coli under control of the maize ubiquitin1 promoter with first intron) as transformation marker, together with $7 \mu \mathrm{g}$ of empty pIPKTA30N vector, pPIKTA30N-BI-1, or pIPKTA36 (MLO RNAi). Leaf segments were bombarded with coated gold particles $72 \mathrm{~h}$ prior to inoculation with spores of B. graminis f. sp. hordei isolate $\mathrm{CH} 4.8$. At $40 \mathrm{HAI}$, GUS activity staining was performed. For this, leaves were vacuum infiltrated with a GUS-staining solution containing the GUSsubstrate 5-bromo-4-chloro-3-indoxyl- $\beta$-D-glucuronic acid (Biosynth AG, Staad, Switzerland) and $1.4 \mathrm{mM}$ K-hexacyanoferrat(II) and K-hexacyanoferrat(III) each, and then incubated overnight at $37^{\circ} \mathrm{C}$ as described by Schweizer and associates (1999). Leaves were destained in 7.5\% (wt/vol) trichloroacetic acid and 50\% methanol for 5 min and then examined under the light microscope. The susceptibility index was calculated as number of penetrated GUS cells divided by the total number of GUS cells multiplied by 100 . In each individual experiment, between 100 and 340 GUS-expressing cells were evaluated per variant. All together, six independent experiments were conducted.

\section{Simultaneous overexpression \\ of $M L O$ and knockdown of $B I-1$.}

For simultaneous $M L O$ overexpression and $B I-1$ TIGS, we ballistically transferred $0.5 \mu \mathrm{g}$ per shot of an $M L O$ overexpression construct (pGY-1-MLO) (Eichmann et al. 2004) together with $1 \mu \mathrm{g}$ per shot of either TIGS vector pIPKTA30N-BI-1 or empty vector pIPKTA30N into epidermal cells of the $B$. graminis f. sp. hordei-resistant barley backcross line BCPallasmlo5. Control cells were cobombarded with $0.5 \mu \mathrm{g}$ per shot of empty pGY-1 vector and $1 \mu \mathrm{g}$ per shot of pIPKTA30N-BI-1. GFP served as transformation marker. Three independent experiments were conducted.

\section{Transient knockdown of GFP-BI-1 expression.}

Barley cv. Ingrid epidermal cells were transiently transformed by particle bombardment with $1 \mu \mathrm{g}$ per shot of the RNAi vector pIPKTA30N-BI-1 or empty vector pIPKTA30N together with $1 \mu \mathrm{g}$ of the pGY-1-GFP-BI-1 (GFP-BI-1 under the control of the constitutive CaMV 35S promoter) construct. As reporter gene, $0.5 \mu \mathrm{g}$ of pGY-1-DsRED was simultaneously cotransformed. Two days after bombardment, DsRED-expressing cells were inspected for presence or absence of GFP-BI-1 fluorescence by microscopy; 100 cells per variant were examined in three independent experiments.

\section{Cell-death assay.}

For the examination of cellular viability after TIGS, we used particle bombardment to codeliver $7 \mu \mathrm{g}$ per shot of RNAi vector pIPKTA30N-BI-1 or empty vector pIPKTA30N together with $7 \mu \mathrm{g}$ of the $B$-Peru/Cl-expression plasmid $\mathrm{pBC} 17$ (Schweizer et al. 2000) and pGY-1-GFP into epidermal cells of barley cv. Golden Promise primary leaves. Five days after transformation, GFP-expressing cells were examined for the presence or absence of red anthocyanin pigments (Schweizer et al. 2000) using fluorescence and bright-field microscopy, respectively. Three independent experiments were conducted with and without inoculation, respectively. Inoculation was conducted 3 days after transformation and 2 days prior to microscopic inspection. In each individual experiment, between 120 and 340 GFP-expressing cells were evaluated per variant.

\section{Examination of basal powdery mildew resistance on transgenic BI-1 RNAi barley plants.}

Binary pLH6000-BI-1 RNAi vector was constructed by introducing a SalI fragment containing inverted repeats of the full-length $B I-1$ cDNA, which are separated by the second intron of the wheat $R G A 2$ gene, into the vector pUbi-ABM (DNA Cloning Service, Hamburg, Germany) between the promoter of the maize UBIQUITIN1 gene with first intron and the terminator of the Agrobacterium tumefaciens NOPALINE SYNTHASE gene. The resulting Ubilp-BI-1-Nost RNAi cassette was then transferred into the pLH6000 vector (GenBank accession number AY234328) (DNA Cloning Service) using SfiI restriction sites, resulting in pLH6000-BI-1 RNAi (Fig. 5A), which was introduced into Agrobacterium strain AGL-1. Stably transgenic barley lines were then generated using immature embryos of cv. Golden Promise according to Hensel and coworkers (2008).

Per experiment, $10 \mathrm{~T} 1$ plants of each independent transgenic line were grown along with control plants of the nontransgenic parental line Golden Promise. First leaves were used to test for the presence of the transgene by genomic PCR after DNA extraction with the REDExtract-N-Amp plant PCR kit (SigmaAldrich Chemie GmbH, Munich) (Babaeizad et al. 2009), using primers 5'-GGATAGCCCTCATAGATAGAGTACTAAC TAA-3' (RGA2 intron-specific) and 5'-ACCCTGTCACGAGG ATGCTT-3' (BI-1-specific). Alternatively, segments of first leaves were tested for their ability to stay green after 7 days on hygromycin-containing (hygromycin B at $200 \mathrm{mg} \mathrm{liter}^{-1}$ ) $0.5 \%$ water agar plates, which is conferred by the HYGROMYCIN PHOSPHOTRANSFERASE gene on the T-DNA. Second leaves were then used for $B$. graminis f. sp. hordei resistance assays. For this, leaf segments were placed on $0.5 \%$ water agar plates and then inoculated with 3 to 5 conidia $\mathrm{mm}^{-2}$. At 5 to 7 days after inoculation, the number of pustules per centimeter of leaf segment was assessed.

\section{Analysis of BI-1 expression in RNAi barley plants using semiquantitative one-step RT PCR.}

For semiquantitative analysis of $B I-1$ expression, total RNA of plants of pLH6000-BI-1 RNAi lines BG37/2E05, BG37/ 2E10, BG37/2E11, and GP WT was extracted (described above). To check for equal RNA concentrations, $2 \mu \mathrm{g}$ of total RNA was loaded onto a denaturing agarose gel (Fig. 5B). Semiquantitative one-step RT-PCR was performed using the OneStep RT-PCR Kit (Qiagen $\mathrm{GmbH}$ ), according to the manufacturer's instructions. Primers 5'-GTCCCACCTCAAGCTCG TTT-3' and 5'-ACCCTGTCACGAGGATGCTT-3' were used to examine $B I-1$ expression and $5^{\prime}$-ACCCTCGCCGACTACA ACAT-3' and 5'-CAGTAGTGGCGGTCGAAGTG-3' were used for the analysis of constitutively expressed UBIQUITIN (GenBank accession number M60175).

\section{Analysis of BI-1 expression in RNAi barley plants using quantitative real-time PCR.}

Quantitative real-time PCR was performed to analyze BI-I expression in stably transgenic pLH6000-BI-1 RNAi plants. Total RNA of four plants of pLH6000-BI-1 RNAi line BG37/ 2E10 and GP WT was extracted (described above) and then 
pooled. Total RNA ( $1 \mu \mathrm{g})$ of each barley line was converted to cDNA template using the QuantiTect reverse transcription kit (Qiagen $\mathrm{GmbH}$ ) according to the manufacturer's instructions. Control reactions confirmed that no interfering genomic DNA was present. Primers 5'-GTCCCACCTCAAGCTCGTTT-3' and 5'-ACCCTGTCACGAGGATGCTT-3' were used to amplify a BI-1 cDNA fragment (GenBank accession number AJ290421) (Deshmukh et al. 2006). Primers 5'-TCTCGTCCCTGAGATT GCCCACAT-3' and 5'-TTTCTCGGGACAGCAACACAATC TTCT-3' were used to amplify a barley UBIQUITIN CONJUGATING ENZYME 2 (UBC2, GenBank accession number AY220735) (Jensen et al. 2007) cDNA fragment, which served as endogenous control to normalize variations in quantity of cDNA. Primer pairs were tested for similar amplification efficiency. Triplicate quantitative RT-PCR analyses were then performed using SsoFast EvaGreen Supermix (Bio-Rad Laboratories $\mathrm{GmbH}$ ) with $100 \mathrm{ng}$ of cDNA each. PCR was carried out on the Mx3005P Real-Time PCR System (Stratagene, La Jolla, CA, U.S.A.) under the following conditions: $95^{\circ} \mathrm{C}$ for $10 \mathrm{~min}$ and 40 cycles of $95^{\circ} \mathrm{C}$ for $30 \mathrm{~s}, 60^{\circ} \mathrm{C}$ for $30 \mathrm{~s}$, and $72^{\circ} \mathrm{C}$ for 30 $\mathrm{s}$. All products were subjected to melting curve analysis. Relative gene expression differences were calculated using the comparative cycle threshold $\left(\mathrm{C}_{\mathrm{T}}\right)$ method $\left(\Delta \Delta \mathrm{C}_{\mathrm{T}}\right)$ (Libault et al. 2007).

\section{Histological staining and microscopic analysis of stably transgenic BI-1 RNAi plants.}

Second leaves of PCR-tested BI-I RNAi plants of line BG37/2E10 as well as corresponding azygous controls that had lost the transgene due to segregation (PCR negative plants) and parental line Golden Promise were inoculated with spores of $B$. graminis f. sp. hordei and, 30 h later, stained with DAB for $6 \mathrm{~h}$ to detect whole-cell $\mathrm{H}_{2} \mathrm{O}_{2}$ accumulation (ThordalChristensen et al. 1997; Hückelhoven et al. 1999). Leaves of intact plants were inoculated. Leaves were destained and fixed as described previously (Hückelhoven and Kogel 1998). For bright-field microscopy, fungal structures were stained with acetic ink (10\% [vol/vol] blue ink in $25 \%$ acetic acid). Successful fungal penetration was indicated by haustorium formation and development of elongated secondary hyphae. Nonpenetrated cells either survived fungal attack (nonpenetrated living cells) or displayed HR, as indicated by whole-cell DAB staining without visible haustorium formation.

\section{ACKNOWLEDGMENTS}

This work was supported by a research grant to R. Hückelhoven from the German Research Foundation, to P. Schweizer and J. Shaw from the German Federal Ministry of Education and Research, and to C. Lacomme from The Scottish Government Rural and Environment Research and Analysis Directorate (RERAD). We thank A. Alkofer, H. Nierig, and C. Marthe for excellent technical assistance.

\section{LITERATURE CITED}

Altenbach, D., and Robatzek, S. 2007. Pattern recognition receptors: From the cell surface to intracellular dynamics. Mol. Plant-Microbe Interact. 209:1031-1039.

Babaeizad, V., Imani, J., Kogel, K. H., Eichmann, R., and Hückelhoven, R. 2009. Over-expression of the cell death regulator BAX inhibitor-1 in barley confers reduced or enhanced susceptibility to distinct fungal pathogens. Theor. Appl. Genet. 1183:455-463.

Bai, Y., Pavan, S., Zheng, Z., Zappel, N. F., Reinstädler, A., Lotti, C., De Giovanni, C., Ricciardi, L., Lindhout, P., Visser, R., Theres, K., and Panstruga, R. 2008. Naturally occurring broad-spectrum powdery mildew resistance in a Central American tomato accession is caused by loss of Mlo function. Mol. Plant-Microbe Interact. 21:30-39.

Bent, A. F., and Mackey, D. 2007. Elicitors, effectors, and $R$ genes: The new paradigm and a lifetime supply of questions. Annu. Rev. Phytopathol. 45:399-436.
Bhat, R. A., Miklis, M., Schmelzer, E., Schulze-Lefert, P., and Panstruga, R. 2005. Recruitment and interaction dynamics of plant penetration resistance components in a plasma membrane microdomain. Proc. Natl. Acad. Sci. U.S.A. 102:3135-3140.

Boller, T., and Felix, G. 2009. A renaissance of elicitors: Perception of microbe-associated molecular patterns and danger signals by pattern-recognition receptors. Annu. Rev. Plant Biol. 60:379-406.

Bryngelsson, T., Sommer-Knudsen, J., Gregersen, P. L., Collinge, D. B., Ek, B., and Thordal-Christensen, H. 1994. Purification, characterization, and molecular cloning of basic PR-1-type pathogenesis-related proteins from barley. Mol. Plant-Microbe Interact. 7:267-275.

Büschges, R., Hollricher, K., Panstruga, R., Simons, G., Wolter, M., Frijters, A., van Daelen, R., van der Lee, T., Diergaarde, P., Groenendijk, J., Töpsch, S., Vos, P., Salamini, F., and Schulze-Lefert, P. 1997. The barley Mlo gene: A novel control element of plant pathogen resistance. Cell 88:695-705.

Chae, H. J., Kim, H. R., Xu, C., Bailly-Maitre, B., Krajewska, M., Krajewski, S., Banares, S., Cui, J., Digicaylioglu, M., Ke, N., Kitada, S., Monosov, E., Thomas, M., Kress, C. L., Babendure, J. R., Tsien, R. Y., Lipton, S. A., and Reed, J. C. 2004. BI-1 regulates an apoptosis pathway linked to endoplasmic reticulum stress. Mol. Cell. 15:355-366.

Chisholm, S. T., Coaker, G., Day, B., and Staskawicz, B. J. 2006. Hostmicrobe interactions: Shaping the evolution of the plant immune response. Cell 124:803-814.

Consonni, C., Humphry, M. E., Hartmann, H. A., Livaja, M., Durner, J., Westphal, L., Vogel, J., Lipka, V., Kemmerling, B., Schulze-Lefert, P., Somerville, S. C., and Panstruga, R. 2006. Conserved requirement for a plant host cell protein in powdery mildew pathogenesis. Nat. Genet. 38:716-720.

Deshmukh, S., Hückelhoven, R., Schäfer, P., Imani, J., Sharma, M., Weiss, M., Waller, F., and Kogel, K. H. 2006. The root endophytic fungus Piriformospora indica requires host cell death for proliferation during mutualistic symbiosis with barley. Proc. Natl. Acad. Sci. U.S.A. 103:18450-18457.

Dietrich, C., and Maiss, E. 2002. Red fluorescent protein DsRed from Discosoma sp. as a reporter protein in higher plants. Biotechniques 32:286291.

Douchkov, D., Nowara, D., Zierold, U., and Schweizer, P. 2005. A highthroughput gene-silencing system for the functional assessment of defense-related genes in barley epidermal cells. Mol. Plant-Microbe Interact. 18:755-761.

Eckardt, N. A. 2002. Plant disease susceptibility genes? Plant Cell 14:1983-1986

Eckey, C., Korell, M., Leib, K., Biedenkopf, D., Jansen, C., Langen, G., and Kogel, K. H. 2004. Identification of powdery mildew-induced barley genes by cDNA-AFLP: Functional assessment of an early expressed MAP kinase. Plant Mol. Biol. 55:1-15.

Eichmann, R., and Hückelhoven, R. 2008. Accommodation of powdery mildew fungi in intact plant cells. J. Plant Physiol. 165:5-18.

Eichmann, R., Schultheiss, H., Kogel, K. H., and Hückelhoven, R. 2004. The barley apoptosis suppressor homologue BAX inhibitor-1 compromises nonhost penetration resistance of barley to the inappropriate pathogen Blumeria graminis f. sp. tritici. Mol. Plant-Microbe Interact. 17:484-490.

Eichmann, R., Biemelt, S., Schäfer, P., Scholz, U., Jansen, C., Felk, A., Schäfer, W., Langen, G., Sonnewald, U., Kogel, K. H., and Hückelhoven, R. 2006a. Macroarray expression analysis of barley susceptibility and nonhost resistance to Blumeria graminis. J. Plant Physiol. 163:657-670.

Eichmann, R., Dechert, C., Kogel, K. H., and Hückelhoven, R. 2006b. Transient over-expression of barley BAX Inhibitor-1 weakens oxidative defence and MLA12-mediated resistance to Blumeria graminis $\mathrm{f}$. $\mathrm{sp}$ hordei. Mol. Plant Pathol. 7:543-552.

Elliott, C., Zhou, F., Spielmeyer, W., Panstruga, R., and Schulze-Lefert, P. 2002. Functional conservation of wheat and rice Mlo orthologs in defense modulation to the powdery mildew fungus. Mol. Plant-Microbe Interact. 15:1069-1077.

Feechan, A., Jermakow, A. M., Torregrosa, L., Panstruga, R., and Dry, I. B. 2008. Identification of grapevine $M L O$ gene candidates involved in susceptibility to powdery mildew. Funct. Plant Biol. 35:1255-1266.

Haupt, S., Duncan, G. H., Holzberg, S., and Oparka, K. J. 2001. Evidence for symplastic phloem unloading in sink leaves of barley. Plant Physiol. 125:209-218

Hein, I., Barciszewska-Pacak, M., Hrubikova, K., Williamson, S., Dinesen, M., Soenderby, I. E., Sundar, S., Jarmolowski, A., Shirasu, K., and Lacomme, C. 2005. Virus-induced gene silencing-based functional characterization of genes associated with powdery mildew resistance in barley. Plant Physiol. 138:2155-2164.

Hensel, G., Valkov, V., Middlefell-Williams, J., and Kumlehn, J. 2008. Efficient generation of transgenic barley: The way forward to modulate plant-microbe interactions. J. Plant Physiol. 165:71-82. 
Holzberg, S., Brosio, P., Gross, C., and Pogue, G. P. 2002. Barley stripe mosaic virus-induced gene silencing in a monocot plant. Plant J. 30:315-327.

Hückelhoven, R. 2004. BAX inhibitor-1, an ancient cell death suppressor in animals and plants with prokaryotic relatives. Apoptosis 9:299-307.

Hückelhoven R. 2005. Powdery mildew susceptibility and biotrophic infection strategies. FEMS (Fed. Eur. Microbiol. Soc.) Microbiol. Lett. 245:9-17.

Hückelhoven, R., and Kogel, K. H. 1998. Tissue-specific superoxide generation at interaction sites in resistant and susceptible near-isogenic barley lines attacked by the powdery mildew fungus (Erysiphe graminis $\mathrm{f}$. sp. hordei). Mol. Plant-Microbe Interact. 11:292-300.

Hückelhoven, R., Fodor, J., Preis, C., and Kogel, K. H. 1999. Hypersensitive cell death and papilla formation in barley attacked by the powdery mildew fungus are associated with hydrogen peroxide but not with salicylic acid accumulation. Plant Physiol. 119:1251-1260.

Hückelhoven, R., Dechert, C., Trujillo, M., and Kogel, K. H. 2001. Differential expression of putative cell death regulator genes in near-isogenic, resistant and susceptible barley lines during interaction with the powdery mildew fungus. Plant Mol. Biol. 47:739-748.

Hückelhoven, R., Dechert, C., and Kogel, K. H. 2003. Overexpression of barley BAX inhibitor 1 induces breakdown of $m l o$-mediated penetration resistance to Blumeria graminis. Proc. Natl. Acad. Sci. U.S.A. 100:5555-5560.

Ihara-Ohori, Y., Nagano, M., Muto, S., Uchimiya, H., and Kawai-Yamada, M. 2007. Cell death suppressor Arabidopsis bax inhibitor-1 is associated with calmodulin binding and ion homeostasis. Plant Physiol. 143:650-660.

Jensen, M. K., Rung, J. H., Gregersen, P. L., Gjetting, T., Fuglsang, A. T., Hansen, M., Joehnk, N., Lyngkjaer, M. F., and Collinge, D. B. 2007. The HvNAC6 transcription factor: A positive regulator of penetration resistance in barley and Arabidopsis. Plant Mol. Biol. 65:137-150.

Jones, J. D. G., and Dangl, J. L. 2006. The plant immune system. Nature 444:323-329

Jørgensen, J. H. 1992. Discovery, characterization and exploitation of Mlo powdery mildew resistance in barley. Euphytica 63:141-52.

Kawai-Yamada, M., Hori, Z., Ogawa, T., Ihara-Ohori, Y., Tamura, K. Nagano, M., Ishikawa, T., and Uchimiya, H. 2009. Loss of calmodulin binding to Bax inhibitor-1 affects Pseudomonas-mediated hypersensitive response-associated cell death in Arabidopsis thaliana. J. Biol. Chem. 284:27998-28003.

Kim, M. C., Panstruga, R., Elliott, C., Müller, J., Devoto, A., Yoon, H. W. Park, H. C., Cho, M. J., and Schulze-Lefert, P. 2002. Calmodulin interacts with MLO protein to regulate defence against mildew in barley. Nature 416:447-451.

Lacomme, C., Hrubikova, K., and Hein, I. 2003. Enhancement of virusinduced gene silencing through viral-based production of invertedrepeats. Plant J. 34:543-553.

Libault, M., Wan, J., Czechowski, T., Udvardi, M., and Stacey, G. 2007. Identification of 118 Arabidopsis transcription factor and 30 ubiquitinligase genes responding to chitin, a plant-defense elicitor. Mol. PlantMicrobe Interact. 20:900-911.

Lorek, J., Panstruga, R., and Hückelhoven, R. 2010. The role of seventransmembrane domain MLO proteins, heterotrimeric G-proteins, and monomeric RAC/ROPs in plant defense. Pages 197-220 in: Integrated G Proteins Signaling in Plants. S. Yalovsky, F. Baluška, and A. Jones, eds. Springer-Verlag, Berlin, Heidelberg, Germany.

Lorrain, S., Vailleau, F., Balagué, C., and Roby, D. 2003. Lesion mimic mutants: Keys for deciphering cell death and defense pathways in plants? Trends Plant Sci. 8:263-271.
Meng, Y., Moscou, M. J., and Wise, R. P. 2009. Blufensin1 negatively impacts basal defense in response to barley powdery mildew. Plant Physiol. 149:271-285.

Nagano, M., Ihara-Ohori, Y., Imai, H., Inada, N., Fujimoto, M., Tsutsumi, N., Uchimiya, H., and Kawai-Yamada, M. 2009. Functional association of cell death suppressor, Arabidopsis Bax inhibitor-1, with fatty acid 2hydroxylation through cytochrome b. Plant J. 58:122-134.

Niks, R. E., and Marcel, T. C. 2009. Nonhost and basal resistance: How to explain specificity? New Phytol. 182:817-828.

O'Connell, R. J., and Panstruga, R. 2006. Tête à tête inside a plant cell: Establishing compatibility between plants and biotrophic fungi and oomycetes. New Phytol. 171:699-718.

Pathuri, I. P., Zellerhoff, N., Schaffrath, U., Hensel, G., Kumlehn, J., Kogel, K. H., Eichmann, R., and Hückelhoven, R. 2008. Constitutively activated barley ROPs modulate epidermal cell size, defense reactions and interactions with fungal leaf pathogens. Plant Cell Rep. 27:1877-1887.

Raffaele, S., Leger, A., and Roby, D. 2009. Very long chain fatty acid and lipid signaling in the response of plants to pathogens. Plant Signal. Behav. 4:94-99.

Schultheiss, H., Dechert, C., Kogel, K. H., and Hückelhoven, R. 2002. A small GTP-binding host protein is required for entry of powdery mildew fungus into epidermal cells of barley. Plant Physiol. 128:14471454.

Schweizer, P. 2007. Nonhost resistance of plants to powdery mildew-new opportunities to unravel the mystery. Physiol. Mol. Plant Pathol. 70:3-7.

Schweizer, P. 2008. Tissue-specific expression of a defence-related peroxidase in transgenic wheat potentiates cell death in pathogen-attacked leaf epidermis. Mol. Plant Pathol. 9:45-57.

Schweizer, P., Pokorny, J., Abderhalden, O., and Dudler, R. 1999. A transient assay system for the functional assessment of defense-related genes in wheat. Mol. Plant-Microbe Interact. 12:647-654.

Schweizer, P., Pokorny, J., Schulze-Lefert, P., and Dudler, R. 2000. Double-stranded RNA interferes with gene function at the single-cell level in cereals. Plant J. 24:895-903.

Shirasu, K., Nielsen, K., Piffanelli, P., Oliver, R., and Schulze-Lefert, P. 1999. Cell-autonomous complementation of mlo resistance using a biolistic transient expression system. Plant J. 17:293-299.

Stolzenburg, M. C., Aist, J. R., and Israel, H. W. 1984. The role of papillae in resistance to powdery mildew conditioned by the $\mathrm{ml}$ - $o$ gene in barley. I Correlative evidence. Physiol. Plant Pathol. 25:337-346.

Thordal-Christensen, H. 2003. Fresh insights into processes of nonhost resistance. Curr. Opin. Plant Biol. 6:351-357.

Thordal-Christensen, H., Zhang, Z., Wei, Y., and Collinge, D. B. 1997. Subcellular localization of $\mathrm{H}_{2} \mathrm{O}_{2}$ in plants. $\mathrm{H}_{2} \mathrm{O}_{2}$ accumulation in papillae and hypersensitive response during the barley-powdery mildew interaction. Plant J. 11:1187-1194.

Watanabe, N., and Lam, E. 2006. Arabidopsis Bax inhibitor-1 functions as an attenuator of biotic and abiotic types of cell death. Plant J. 45:884894.

Watanabe, N., and Lam, E. 2009. Bax inhibitor-1, a conserved cell death suppressor, is a key molecular switch downstream from a variety of biotic and abiotic stress signals in plants. Int. J. Mol. Sci. 10:31493167

Wei, Y., Zhang, Z., Andersen, C. H., Schmelzer, E., Gregersen, P. L., Collinge, D. B., Smedegaard-Petersen, V., and Thordal-Christensen, H. 1998. An epidermis/papilla-specific oxalate oxidase-like protein in the defence response of barley attacked by the powdery mildew fungus. Plant Mol. Biol. 36:101-112.

Zipfel, C. 2008. Pattern-recognition receptors in plant innate immunity. Curr. Opin. Immunol. 20:10-16. 